\title{
Does the Recent Global Business Growth Exhibit An Inclusive Growth? a Research on Socio-Economic Status of Least Developed Nations in Asia
}

\author{
T.Sisili. D.David Winster Praveenraj
}

\begin{abstract}
While the global business growth trend is upward, it is essential to ensure that if it is an inclusive growth that every nation is benefited and growing. Asia is the earth's largest continent. It covers 48 countries. This article focuses on the socio-economic status of the nine least developed countries in Asia to validate whether the global economic growth is inclusive. It examines how Socio-economic status fosters or hinders the development of these countries. Regression analysis is used for analyzing the Gross National Income, Foreign direct investment.
\end{abstract}

Keywords: Socio-Economic Status, Inclusive growth, Least Developed Nations, Gross Domestic Product, Life expectancy, JEL Classification: E0

\section{INTRODUCTION}

United Nations Conference on Trade and Development (UNCTAD I), was held at Geneva in 1964. In this conference member countries recognized international policy to promote economically very poor countries especially least developed countries at world level. [1] The characteristics of least developed countries are deeper poverty, illiteracy, unemployment, epidemics, lack of proper economic development process, natural and manmade disasters. These countries need more financial support from other countries for sustained growth and to ensure inclusive growth that all nations are reaping benefits of the overall global economic growth. $12 \%$ of the world's population living in the least developed countries. These countries secure less than $2 \%$ of world's GDP and 1\% of world's trade. [2] To classify nations, United Nations selected 3 indicators, which are GDP per capita, share of manufacturing in GDP and adult literacy rate.[3] Afghanistan, Bangladesh, Bhutan, Cambodia, Myanmar, Nepal, Timor-Leste and Yemen are least developed countries in Asia. This article focuses on the socio-economic status of nine least developed countries in Asia for the calendar year 2001-2017.

Manuscript published on November 30, 2019

* Correspondence Author

Mr.T.Sisili*, School of Management Studies, Bannari Amman Institute of Technology, Tamilnadu, India. Email: sisili@bitsathy.ac.in.

Mr.D.David Winster Praveenraj*, School of Management Studies, Bannari Amman Institute of Technology, Tamilnadu, India. Email: ddavidwins@gmail.com

(C) The Authors. Published by Blue Eyes Intelligence Engineering and Sciences Publication (BEIESP). This is an open access article under the CC-BY-NC-ND license http://creativecommons.org/licenses/by-nc-nd/4.0/

\section{REVIEW OF LITERATURE}

This section reviews earlier research papers, articles, and experts on this area of research for a clear understanding. According to Dutton and Levine (1989), socio-economic status is measured on the basis of Income, education; job and standard of living of the person [4].

Grimmett, P. and Suzanne Majhanovich (1995) examined about Laos teacher education, The education department fails to give better solutions for their problems and not concentrated on independent ideas and analysis [5].

AKM AbdusSabur (1999) examined that the Bangladesh and India contrast in socio-economic, cultural, political and geographical conditions. But in some factors, both are closely related and interdependent. Even though both are having some conflicts in their ideas it will not affect bilateral trade of these countries [6].

Dhungal K.R. (2003) examined, due to the demand of electricity and fossil fuels Nepal will start more electricity generation plants and import more fuels and also to increase the investment in hydropower sector for staple economic growth [7].

Weggel, Oskar (January 2006) analyzed about foreign aid which revealed that due to government's weak policies, the absence of implementing anti-corruption laws, and not concentrating in the education system, Cambodia faced worse situation in 2005[8].

Lee, Joosung J (May-June 2011) examined that the effect of economic crisis on the major economic sectors. Because of economic crisis Cambodia's garments exports to U.S. and Europe was reduced in the year 2008. As a result, thousands of garment workers lost their jobs. At the end of 2009 and beginning of 2010 Cambodian economy slightly improved. However, in Cambodia nearly 2.8 million people live below the poverty line [9]

As per the World Bank report, (2016) Compared to 1972 in the year 2010 and 2016 poverty rate of Bangladesh was reduced tremendously [10]. World bank (2016), Misha, Farzana; Sulaiman examined (2016), due to the reduction of poverty rate of Bangladesh in future it will become one of the higher income earning economy in South Asia [11,12]. Cecilia Tortajada (2016) analyzed that the least developing countries in Asia are segregated on the basis of their export specialization. 


\section{Does The Recent Global Business Growth Exhibit An Inclusive Growth? A Research on Socio - Economic Status of Least Developed Nations in Asia}

Bangladesh, Bhutan, and Cambodia are specialized in Manufacturing, Laos and Myanmar comes under the mixed exporter's category. Service exporters are Afghanistan and Nepal. Yemen is a fuel exporter [13] hence; this article has made an attempt to study the prevailing gap in the earlier studies and minimized the research gap by analyzing the various socio-economic statuses of nine least developed countries in Asia.

\section{OBJECTIVES OF THE STUDY}

To analyze the role of selected socio-economic indicators in the development of least developed countries in Asia. To assess whether the global economic growth is inclusive this results in development across nations.

\section{METHODOLOGY}

The period of study has covered 17 calendar years from 2001-2017. This period was chosen because during this period dynamic socio-economic and political changes happened throughout the world including the LDC's in Asia. Secondary data was collected from world development indicators. Regression analysis was used for analyzing Gross
National Income, Foreign direct investment - Inflow (\% of GDP) and Life expectancy at birth (total). Percentage (annual) analysis was used for Country wise GDP per capita growth and Sector wise employment. This study has used percentage growth for estimating the total population in nine least developed countries in Asia from 2001 to 2017

\section{DATA ANALYSIS \& INTERPRETATION}

\subsection{Regression analysis for 'Gross National Income'}

A regression analysis was conducted with dependent variable 'Gross National Income (current US\$) and the independent variables Total Population, Gross national income per capita growth (annual \%), Poverty headcount ratio at national poverty lines (\% of the population).

Hypothesis:

H0: There is no significant difference between the independent variables that are influencing the dependent variable 'Gross National Income (current US\$)

$\mathrm{H1}$ : There is a significant difference between the independent variables that are influencing the dependent variable 'Gross National Income (current US\$)

Table 1 Model Summary - Gross National Income (current US\$)

\begin{tabular}{|c|c|c|c|c|}
\hline Model & R & R Square & Adjusted R Square & Std. Error of the Estimate \\
\hline 1 & $.907^{\mathrm{a}}$ & .823 & .795 & 0.00002409 \\
\hline
\end{tabular}

a. Predictors: (Constant), Poverty headcount ratio at national poverty lines (\% of population),

Population, total, GNI per capita growth (annual \%)

Table 2 Regression and Error values

\begin{tabular}{|l|l|r|r|r|r|}
\hline \multicolumn{2}{|l|}{ Model } & Sum of Squares & Df & Mean Square & \multicolumn{1}{c|}{ Sig. } \\
\hline 1 & Regression & $5.112 \mathrm{E} 22$ & 3 & $1.704 \mathrm{E} 22$ & 29.356 \\
& Residual & $1.103 \mathrm{E} 22$ & 19 & $5.805 \mathrm{E} 20$ & \\
\cline { 2 - 6 } & Total & $6.215 \mathrm{E} 22$ & 22 & & \\
\end{tabular}

a. Predictors: (Constant), Poverty headcount ratio at national poverty lines (\% of population), Population, total, GNI per capita growth (annual \%)

b. Dependent Variable: GNI (current US\$)

Table 3 Coefficients of dependent variables

\begin{tabular}{|l|r|r|}
\hline \multicolumn{1}{|c|}{ Variables } & \multicolumn{2}{c|}{ Coefficients } \\
\cline { 2 - 3 } & \multicolumn{1}{c|}{ B } & \multicolumn{1}{c|}{ Std. Error } \\
\hline (Constant) & 0.00001043 & 0.00001652 \\
\hline Population, total & 975.485 & 104.543 \\
\hline GNI per capita growth (annual \%) & 0.00002755 & 0.00004 .935 \\
\hline Poverty headcount ratio at national poverty lines (\% of population) & -0.0000423 & 0.00004891 \\
\hline
\end{tabular}

Regression equation:

GNI (CUSD) $=\mathbf{a}_{1}+\boldsymbol{\alpha}_{1}$ POPT $+\boldsymbol{\alpha}_{2}$ GNIPCP $+\boldsymbol{\alpha}_{3} \mathrm{PHCH}+$

$\varepsilon_{1}$

Where,

\footnotetext{
GNI (CUSD) - Gross National Income (current US\$)

POPT - Total Population

GNIPCP - GNI per capita growth (annual \%)
}

PHCR - Poverty headcount ratio at national poverty lines (\% of population)

$\mathrm{a}_{1} \quad$-Constant

$\alpha_{1}$ - Coefficient of POPT

$\alpha_{2} \quad-$

Coefficient of POPT

$\alpha_{3} \quad-$

Coefficient of PHCR 

$\varepsilon_{1}$
- Error

By substituting the value from table 3 , the regression equation will be

$$
\text { GNI }(\text { CUSD) }=0.00001+975.485 \mathrm{POPT}+
$$

0.00002755 GNIPCP $-0.0000423 \mathrm{PHCH}+0.823$

\section{Interpretation:}

The Significance (P Value) of the model is 0.00 , which is less than the stipulated P-Value of 0.05 . So this test is statistically significant. The independent variables considered for the test are 'Total Population, GNI per capita growth (annual \%), and Poverty headcount ratio at national poverty lines (\% of the population). By running the regression test the coefficient of predicts and constant value are arrived as a1 $=0.00001043, \alpha 1$ $=975.485, \alpha 2=0.00002755$ and $\varepsilon 1=0.823$

As the p-value is much less than 0.05, (i.e. 0.000), we reject the null hypothesis. Hence there is a significant relationship between the variables in the linear regression model of the data set.

\subsection{Regression analysis for 'Foreign direct investment - Inflow'}

A regression analysis was conducted with dependent variable 'Foreign direct investment - Inflow (\% of GDP) and the independent variables considered were GDP growth (\%), Exports of Goods and Services (\% of GDP) and Imports of Goods and Services (\% of GDP)

Hypothesis:

H0: There is no significant difference between the independent variables that are influencing the dependent variable 'Foreign direct investment -Inflow (\% of GDP) '

$\mathrm{H} 1$ : There is a significant difference between the independent variables that are influencing the dependent variable 'Foreign direct investment -Inflow (\% of GDP) ‘

Table 4 Model Summary - Foreign direct investment -Inflow (\% of GDP)

\begin{tabular}{|c|c|c|c|c|}
\hline Model & R & R Square & Adjusted R Square & Std. Error of the Estimate \\
\hline 1 & $.629^{\mathrm{a}}$ & .396 & .383 & 2.40386 \\
\hline
\end{tabular}

a. Predictors: (Constant), Imports of Goods and Services (\% of GDP), GDP growth (\%),

Exports of Goods and Services (\% of GDP)

Table 5 Regression and Error values

\begin{tabular}{|c|c|c|c|c|c|c|}
\hline & Model & Sum of Squares & df & Mean Square & $\mathbf{F}$ & Sig. \\
\hline \multirow[t]{3}{*}{1} & Regression & 525.662 & 3 & 175.221 & 30.323 & $.000^{\mathrm{a}}$ \\
\hline & Residual & 803.218 & 139 & 5.779 & & \\
\hline & Total & 1328.880 & 142 & & & \\
\hline
\end{tabular}

a. Predictors: (Constant), Imports of Goods and Services (\% of GDP), GDP growth (\%), Exports of

Goods and Services (\% of GDP)

b. Dependent Variable: Foreign direct investment -Inflow (\% of GDP)

Table 6 Coefficients of dependent variables

\begin{tabular}{|c|c|c|}
\hline \multirow{2}{*}{ Variables } & \multicolumn{2}{|c|}{ Coefficients } \\
\cline { 2 - 3 } & B & Std. Error \\
\hline (Constant) & .026 & .437 \\
\hline GDP growth (\%) & .034 & .021 \\
\hline Exports of Goods and Services (\% of GDP) & .113 & .014 \\
\hline Imports of Goods and Services (\% of GDP) & -.016 & .011 \\
\hline
\end{tabular}

Regression equation:

$$
\mathbf{E D I P}=\mathbf{a} 2+\boldsymbol{\alpha}_{\mathbf{4}} \text { EGSP }+\boldsymbol{\alpha}_{5} \text { EGSP }+\boldsymbol{\alpha}_{\mathbf{6}} \text { IGSP }+\boldsymbol{\varepsilon}_{\mathbf{2}}
$$

Where,

$\begin{array}{ll}\text { FDIP } & \text { - Foreign direct investment -Inflow (\% } \\ \text { of GDP) } & \\ \text { EGSP } & \text { - GDP growth (\%) } \\ \text { EGSP } & \text { - Exports of Goods and Services (\% of } \\ \text { GDP) } & \\ \text { IGSP } & \text { - Imports of Goods and Services (\% of } \\ \text { GDP) } & \\ A_{2} & \text {-Constant } \\ \alpha_{4} & \text { - Coefficient of GDPGP } \\ \alpha_{5} & \text { - Coefficient of EGSP } \\ \alpha_{6} & \text { - Coefficient of IGSP } \\ \varepsilon_{2} & \text { - Error }\end{array}$

By substituting the value from table 6 , the regression equation will be

$$
\begin{aligned}
& \mathrm{EDIP}=0.026+0.034 \mathrm{EGSP}+0.113_{\mathrm{EGSP}}-0.016 \\
& \mathrm{IGSP}+0.396
\end{aligned}
$$

\section{Interpretation:}

The Significance (P Value) of the model is 0.00 , which is less than the stipulated P-Value of 0.05 . So this test is statistically significant. The independent variables considered for the test are 'Total Population, GNI per capita growth (annual \%), and Poverty headcount ratio at national poverty lines (\% of the population). By running the regression test the coefficient of predicts and constant value are arrived as a1 $=0.026, \alpha 1$ $=0.04, \alpha 2=0.113$ and $\varepsilon 1=-0.016$ As the p-value is much less than 0.05 , (i.e. 0.000 ), 


\section{Does The Recent Global Business Growth Exhibit An Inclusive Growth? A Research on Socio - Economic Status of Least Developed Nations in Asia}

we reject the null hypothesis. Hence there is a significant relationship between the variables in the linear regression model.

5.3. Regression analysis for 'Literacy rate (Adult)'

A regression analysis was conducted with the dependent variable 'Literacy rate, adult total (\% of people of age 15 and above) and the independent variables considered were Population ( total) Literacy rate- adult female (\% of female of age 15 and above) and Literacy rate - adult male (\% of male of age 15 and above)

Table 7 Model Summary - Literacy rate, adult total (\% of people ages 15 and above)

\begin{tabular}{|l|r|r|r|r|}
\hline Model & \multicolumn{1}{|c|}{ R } & R Square & Adjusted R Square & Std. Error of the Estimate \\
\hline 1 & $1.000^{\mathrm{a}}$ & .999 & .999 & .33748 \\
\hline
\end{tabular}

a. Predictors: (Constant), Population, total, Literacy rate, adult female (\% of females ages 15 and above), Literacy rate, adult male (\% of males ages 15 and above)

Table 8 Regression and Error values

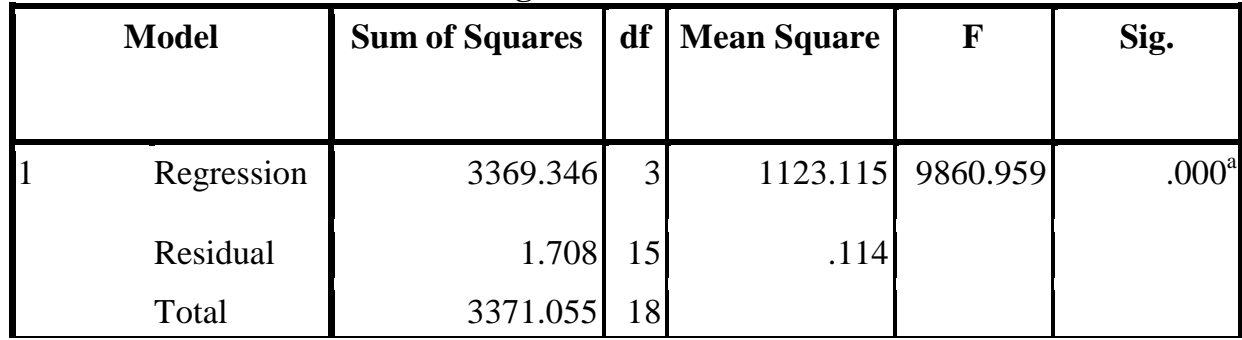

a. Predictors: (Constant), Population, total, Literacy rate, adult female (\% of female of age 15 and above), Literacy rate, adult male (\% of male of age 15 and above)

b. Dependent Variable: Literacy rate, adult total (\% of people age 15 and above)

Table 9 Coefficients of dependent variables

\begin{tabular}{|l|r|r|}
\hline \multicolumn{1}{|c|}{ Variables } & \multicolumn{2}{c|}{ Coefficients } \\
\cline { 2 - 3 } & \multicolumn{1}{c|}{ B } & Std. Error \\
\hline (Constant) & .662 & .568 \\
\hline Literacy rate, adult male (\% of males ages 15 and above) & .495 & .017 \\
\hline Literacy rate, adult female (\% of females ages 15 and above) & .492 & .015 \\
\hline Population, total & 1.286 & .000 \\
\hline
\end{tabular}

Regression equation:

LRTA $=\mathbf{a} 3+\boldsymbol{\alpha}_{7}$ LRMA $+\boldsymbol{\alpha}_{\mathbf{8}}$ LRFA $+\boldsymbol{\alpha}_{\mathbf{9}}$ POPT $+\boldsymbol{\varepsilon}_{3}$ Where,

LRTA
of age 15 and above)
$\begin{array}{ll}\text { LRMA } & \text { - Literacy rate, adult total (\% of people } \\ \text { of age } 15 \text { and above) }\end{array}$
$\begin{array}{ll}\text { LRFA } & \text { - Literacy rate, adult female (\% of } \\ \text { female of age } & 15 \text { and above) } \\ \text { POPT } & \text { - Population, total } \\ a_{3} & \text {-Constant } \\ \alpha_{7} & \text { - Coefficient of LRMA } \\ \alpha_{8} & \text { - Coefficient of LRFA } \\ \alpha_{9} & \text { - Coefficient of POPT } \\ \varepsilon_{3} & \text { - Error }\end{array}$

By substituting the value from table 9 , the regression equation will be

\footnotetext{
LRTA $=0.662+0.495$ LRMA + 0.492 LRFA +

$1.286 \mathrm{POPT}+0.999$
}

\section{Interpretation:}

The Significance (P Value) of the model is 0.00 , which is less than the stipulated P-Value of 0.05 . So this test is statistically significant. The independent variables considered for the test are 'Population (total)', 'Literacy rate- adult female (\% of female of age 15 and above)' and 'Literacy rate - adult male (\% of male of age 15 and above)'. By running that regression test the coefficient of predicts and constant value are arrived as a3 $=0.662, \alpha 7=0.495, \alpha 8=0.492, \alpha 9=1.286$ and $\varepsilon 3=$ 0.999 . As the p-value is much less than 0.05 , (i.e. 0.000), we reject the null hypothesis. Hence there is a significant relationship between the variables in the linear regression.

5.4. Regression analysis for 'Life expectancy at birth (total)' 
A regression analysis was conducted with the dependent variable 'Life expectancy at birth, total (years) 'and by the independent variables consider were Prevalence of HIV, female (\% ages 15-24), Life expectancy at birth, female (years), Prevalence of HIV, male (\% ages 15-24), and Life expectancy at birth, male (years)

Hypothesis:
H0: There is no significant difference between the independent variables that are influencing the dependent variable 'Life expectancy at birth (total)

H1: There is a significant difference between the independent variables that are influencing the dependent variable 'Life expectancy at birth (total)

Analysis:

Table 10 Model Summary - Life expectancy at birth (total)

\begin{tabular}{|l|r|r|r|r|}
\hline Model & \multicolumn{1}{|c|}{$\mathrm{R}$} & R Square & Adjusted R Square & Std. Error of the Estimate \\
\hline 1 & $0.997^{\mathrm{a}}$ & 0.998 & 0.998 & .03633 \\
\hline
\end{tabular}

a. Predictors: (Constant), Prevalence of HIV, female (\% age 15-24), Life expectancy at birth, female (years), Prevalence of HIV, male (\% ages $\backslash 15-24$ ), Life expectancy at birth, male (years)

Table 11 Regression and Error values

\begin{tabular}{|ll|r|r|r|r|r|}
\hline Model & & Sum of Squares & df & Mean Square & \multicolumn{1}{c|}{ F } & Sig. \\
\hline 1 & Regression & 1358.324 & 4 & 339.581 & 257282.177 & $.000^{\mathrm{a}}$ \\
& & .141 & 107 & .001 & & \\
& Residual & 1358.465 & 111 & & & \\
Total & & & & \\
\hline
\end{tabular}

a. Predictors: (Constant), Prevalence of HIV, female (\% ages 15-24), Life expectancy at birth, female (years), Prevalence of HIV, male (\% ages 15-24), Life expectancy at birth, male (years)

b. Dependent Variable: Life expectancy at birth, total (years)

Table 12 Coefficients of dependent variables

\begin{tabular}{|c|c|}
\hline & Variables \\
\hline & (Constant) \\
\hline & Life expectancy at birth, female (years \\
\hline & Life expectancy at birth, male (years) \\
\hline & Prevalence of HIV, male (\% ages $15-2$ \\
\hline & Prevalence of HIV, female (\% ages 15 \\
\hline $\begin{array}{l}\text { Regression equat } \\
\text { LEBT }=\mathbf{a}_{\mathbf{4}}+\boldsymbol{c} \\
\text { HIVF }+\boldsymbol{\varepsilon}_{\mathbf{4}} \\
\text { Where, }\end{array}$ & $\mathrm{BF}+\boldsymbol{\alpha}_{1 \mathbf{1}} \mathrm{LEBM}+\boldsymbol{\alpha}_{\mathbf{1 2}} \mathrm{HIVM}+\boldsymbol{\alpha}_{\mathbf{1 3}}$ \\
\hline LEBT & - Life expectancy at birth (total) \\
\hline $\begin{array}{l}\text { LEBF } \\
\text { (years) }\end{array}$ & - Life expectancy at birth, female \\
\hline LEBM & - Life expectancy at birth, male (years) \\
\hline $\begin{array}{l}\text { HIVM } \\
15-24)\end{array}$ & - Prevalence of HIV, male (\% ages \\
\hline $\begin{array}{l}\text { HIVF } \\
15-24)\end{array}$ & - Prevalence of HIV, female (\% ages \\
\hline$a_{4}$ & -Constant \\
\hline$\alpha_{10}$ & - Coefficient of LEBF \\
\hline$\alpha_{11}$ & - Coefficient of LEBM \\
\hline$\alpha_{12}$ & - Coefficient of HIVM \\
\hline
\end{tabular}

By substituting the value from table 12, the regression equation will be

$$
\begin{aligned}
& \text { LEBT }=\mathbf{0 . 0 1 6}+0.526 \mathrm{LEBF}+0.472 \mathrm{LEBM}- \\
& 0.072 \mathrm{HIVM}+0.82 \mathrm{HIVF}+0.998
\end{aligned}
$$

\section{Interpretation:}

The Significance (P Value) of the model is 0.00 , which is less than the stipulated P-Value of 0.05 . So this test is statistically significant.

The independent variables are considered for the test are 'Prevalence of HIV, female (\% ages 15-24)',

Blue Eyes Intelligence Engineering \& Sciences Publication 


\section{Does The Recent Global Business Growth Exhibit An Inclusive Growth? A Research on Socio - Economic Status of Least Developed Nations in Asia}

'Life expectancy at birth, female (years)', 'Prevalence of HIV, male (\% ages 15-24)' and 'Life expectancy at birth, male (years)'. By running the regression test the co-efficient of predicts and constant value are arrived as $\mathrm{a} 4=0.016, \alpha 10$ $=0.526, \alpha 11=0.472, \alpha 12=-0.072, \alpha 13=-0.082$ and $\varepsilon 3=$
0.998 .As the p-value is much less than 0.05, (i.e. 0.000), we reject the null hypothesis. Hence there is a significant relationship between the variables in the linear regression model.

Table 13 Country wise GDP per capita growth (annual \%) from 2001-to 2017

\begin{tabular}{|c|c|c|c|c|c|c|c|c|c|}
\hline $\begin{array}{l}\text { Year/GDP per } \\
\text { capita growth } \\
\text { (\%)annual }\end{array}$ & 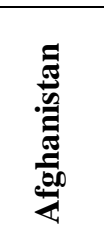 & 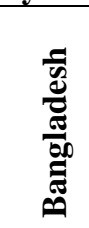 & 苞 & 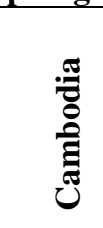 & $\stackrel{n}{\tilde{\omega}}$ & 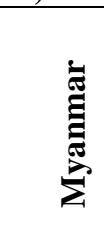 & 茜 & 咅 & $\stackrel{\Xi}{ٍ ٍ ~}$ \\
\hline 2001 & & 3.10 & 5.23 & 5.28 & 4.09 & 10.07 & 2.97 & 6.64 & 0.89 \\
\hline 2002 & & 1.94 & 7.66 & 4.62 & 4.33 & 10.81 & -1.53 & -10.02 & 1.03 \\
\hline 2003 & 3.34 & 2.92 & 4.72 & 6.66 & 4.50 & 12.69 & 2.34 & -4.99 & 0.85 \\
\hline 2004 & -3.36 & 3.54 & 3.11 & 8.56 & 4.76 & 12.50 & 3.20 & 58.17 & 1.09 \\
\hline 2005 & 6.95 & 4.96 & 4.45 & 11.49 & 5.44 & 12.61 & 2.14 & 31.94 & 2.69 \\
\hline 2006 & 2.20 & 5.25 & 4.37 & 9.09 & 6.85 & 12.23 & 2.17 & 38.68 & 0.35 \\
\hline 2007 & 10.65 & 5.77 & 15.40 & 8.58 & 5.78 & 11.25 & 2.33 & 3.56 & 0.53 \\
\hline 2008 & 1.04 & 4.83 & 2.68 & 5.12 & 6.00 & 9.57 & 5.06 & 8.66 & 0.84 \\
\hline 2009 & 17.95 & 3.89 & 4.64 & -1.40 & 5.76 & 9.84 & 3.50 & -7.26 & 1.07 \\
\hline 2010 & 5.43 & 4.40 & 9.71 & 4.34 & 6.89 & 8.86 & 3.72 & -2.73 & 4.82 \\
\hline 2011 & 2.88 & 5.25 & 6.02 & 5.38 & 6.55 & 4.76 & 2.27 & 9.66 & -15.04 \\
\hline 2012 & 10.75 & 5.28 & 3.33 & 5.58 & 6.65 & 6.42 & 3.56 & 2.67 & -0.31 \\
\hline 2013 & 0.51 & 4.77 & 0.54 & 5.60 & 6.71 & 7.45 & 2.88 & -13.08 & 2.09 \\
\hline 2014 & -0.53 & 4.84 & 4.18 & 5.40 & 6.27 & 7.00 & 4.72 & -27.78 & -2.74 \\
\hline 2015 & -1.63 & 5.37 & 5.12 & 5.33 & 5.86 & 6.01 & 2.12 & 18.14 & -38.71 \\
\hline 2016 & -0.35 & 5.96 & 6.59 & 5.29 & 5.53 & 4.91 & -0.72 & -1.38 & -35.93 \\
\hline 2017 & 0.07 & 6.16 & 5.52 & 5.19 & 5.34 & 5.40 & 6.32 & -9.96 & \\
\hline
\end{tabular}

The growth rate of GDP per capita (annual \%) is based on the constant local currency of a country. GDP per capita is gross domestic product divided by midyear population. It is one of the main economic indicators and it is an useful unit to make cross-country comparisons of the average standard of living and good economic progress. Table 13 shows the nine LDC's GDP per capita growth (annual \%) from 2001 to 2017. Out of these nine countries Afghanistan, Cambodia, Nepal, Timor -Leste and Yemen are affected in some years by negative growth of GDP per capita growth(annual\%). Negative growth describes the performance of a company experiencing a decline in sales and earnings and wage growth. Bangladesh, Bhutan, Laos, and Myanmar had positive per capita growth annual percentage it indicates the development of these economies. Yemen's GDP per capita growth (annual \%) had declined tremendously in the year 2015and 2016 compared to other years. In Afghanistan from 2014 to 2016 the GDP per capita growth (annual \%) had continuously declined. In the year 2017, it has slightly increased. In Myanmar, from 2001 to 2006 GDP per capita growth (annual \%) had increased continuously after that some ups and downs happened in Myanmar's per capita GDP growth. During this study period, Timor-Leste had faced negative sign in GDP per capita growth (annual\%) 8 times. This is primarily because of poor economic policies, poverty and unemployment problems etc. Cambodia had faced negative GDP per capita growth (annual
$\%$ ) in the year 2009. Rest of the countries showed positive GDP per capita growth (annual \%). 
Table Number 14 Total population of LDC's in Asia from 2001-2017

\begin{tabular}{|c|c|c|c|c|c|c|c|c|c|}
\hline $\begin{array}{l}\text { Year/Population, Total } \\
\text { (in crores) }\end{array}$ & 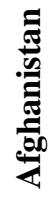 & 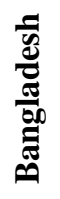 & 苞 & 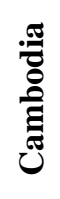 & 疍 & 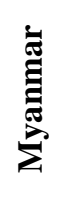 & 苋 & 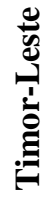 & ت્ّ \\
\hline 2001 & 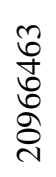 & 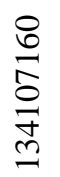 & $\begin{array}{l}\text { \& } \\
\text { \& } \\
\infty \\
\infty\end{array}$ & 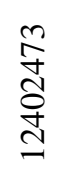 & $\begin{array}{l}\text { 号 } \\
\text { 芳 } \\
\text { 守 }\end{array}$ & \begin{tabular}{l} 
ন \\
సิ \\
ర్ \\
\multirow{v}{*}{}
\end{tabular} & $\begin{array}{l}\hat{N} \\
\hat{N} \\
\vec{\sigma} \\
\stackrel{+}{\Delta}\end{array}$ & $\begin{array}{l}\vec{N} \\
\stackrel{N}{N} \\
\stackrel{\infty}{\infty}\end{array}$ & 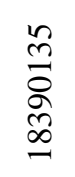 \\
\hline 2002 & 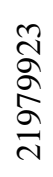 & 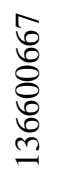 & $\begin{array}{l}\text { बे } \\
\text { ర్ర } \\
\text { ठ }\end{array}$ & 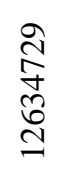 & 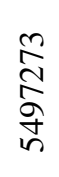 & 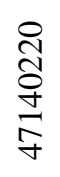 & $\begin{array}{l}\text { Nै } \\
\text { ర్ } \\
\text { In } \\
\stackrel{1}{N}\end{array}$ & 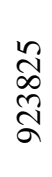 & 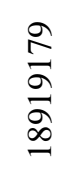 \\
\hline 2003 & 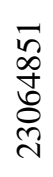 & 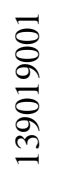 & $\begin{array}{l}\text { ָे } \\
\text { స్ } \\
\text { }\end{array}$ & 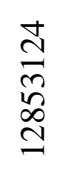 & 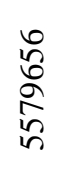 & 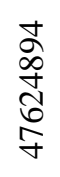 & 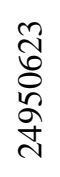 & 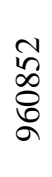 & 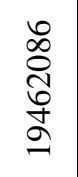 \\
\hline 2004 & 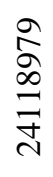 & 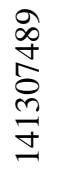 & $\begin{array}{l}\text { ô } \\
\text { ல } \\
\stackrel{+}{0}\end{array}$ & 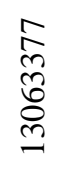 & $\begin{array}{l}\text { L } \\
0 \\
0 \\
0 \\
0 \\
\circ\end{array}$ & 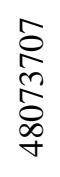 & $\begin{array}{l}\text { 导 } \\
\text { Dे } \\
\text { దू } \\
\text { N }\end{array}$ & $\begin{array}{l}\infty \\
\mathscr{0} \\
\mathscr{8} \\
\mathscr{8}\end{array}$ & 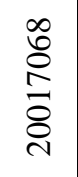 \\
\hline 2005 & 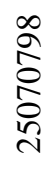 & 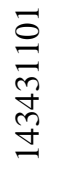 & $\begin{array}{l}\text { శ్ } \\
\text { ర్ } \\
\text { ్ㅐ }\end{array}$ & 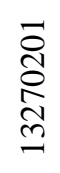 & 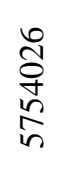 & 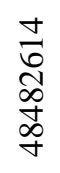 & 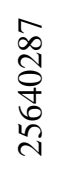 & 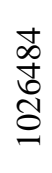 & $\begin{array}{l}\hat{N} \\
\text { Dे } \\
\text { Dे } \\
\text { ટે }\end{array}$ \\
\hline 2006 & 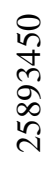 & 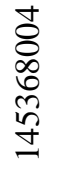 & 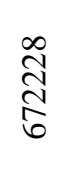 & 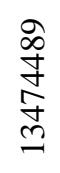 & 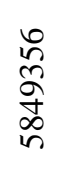 & 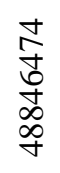 & 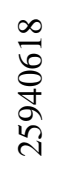 & 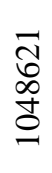 & 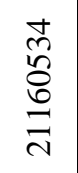 \\
\hline 2007 & 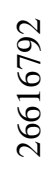 & 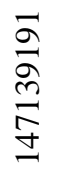 & $\begin{array}{l}\infty \\
\mathscr{1} \\
0 \\
\infty \\
0\end{array}$ & 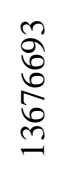 & $\begin{array}{l}\hat{\infty} \\
\stackrel{0}{O} \\
\text { Oे }\end{array}$ & 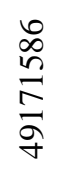 & 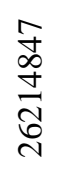 & 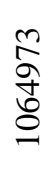 & $\begin{array}{l}\text { L } \\
0 \\
0 \\
1 \\
\hat{N} \\
\vec{N}\end{array}$ \\
\hline 2008 & 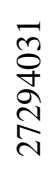 & 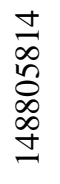 & $\begin{array}{l}\text { ㅇ } \\
\text { مे } \\
\text { 오 }\end{array}$ & 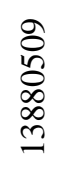 & 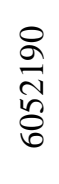 & 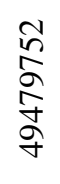 & 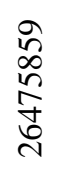 & $\begin{array}{l}\text { 음 } \\
\stackrel{\infty}{0} \\
0 \\
0\end{array}$ & $\begin{array}{l}\vec{D} \\
\text { ర్ } \\
\text { N } \\
\text { ה్ }\end{array}$ \\
\hline
\end{tabular}


Does The Recent Global Business Growth Exhibit An Inclusive Growth? A Research on Socio - Economic Status of Least Developed Nations in Asia

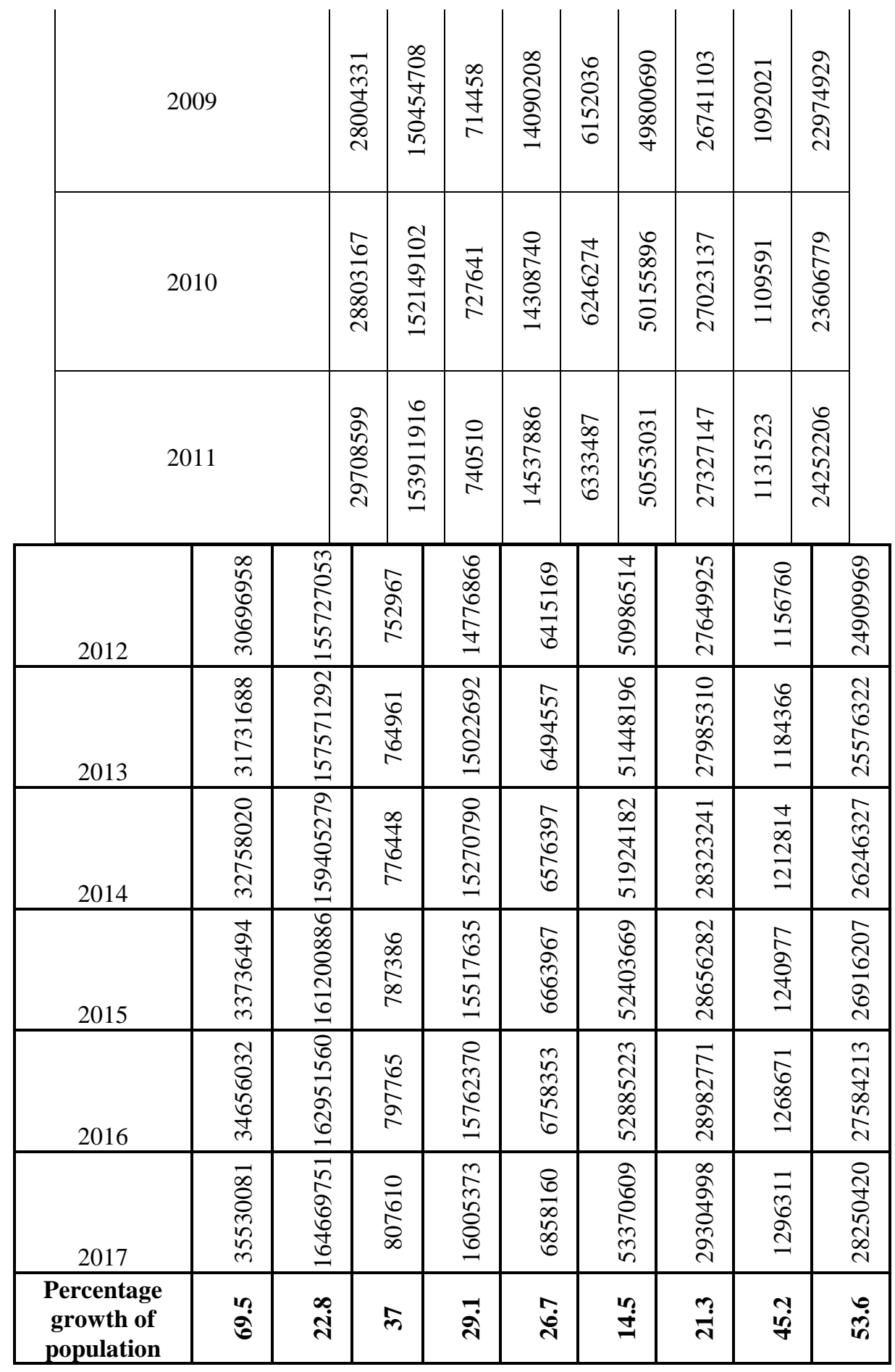

The above table shows that the total population of nine least developing countries in Asia from 2001 to 2017. Out of these 9 LDC's Bangladesh is occupying very first place in terms of population. This country has secured 8th place in the world's population. The density of population is also so high in this country, especially in Dhaka city. It is the largest city in Bangladesh, with a population of 10,356,500 people. Because of high population, this country could not develop economically just like other developed Asian countries. Myanmar is occupying $26^{\text {th }}$ position in total population at world level. One of the biggest problems for the least developed countries is having more population. This will create some obstacles for the development of these countries. Higher population means that the Government should spend more money on public welfare. Hence the growth of the economy will naturally be affected. 
Table No: 15 Sector wise percentage of employment in least developed countries from 2001-2017

\begin{tabular}{|c|c|c|c|c|c|c|c|c|c|}
\hline \multirow[b]{2}{*}{ Year } & \multicolumn{3}{|c|}{ Afghanistan } & \multicolumn{3}{|c|}{ Bangladesh } & \multicolumn{3}{|c|}{ Bhutan } \\
\hline & 这 & 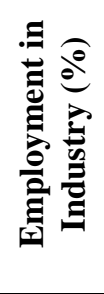 & 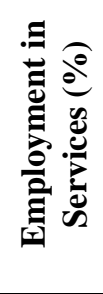 & 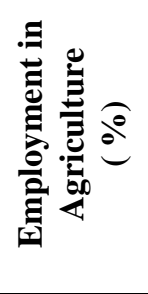 & 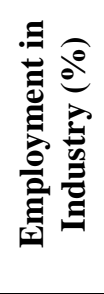 & 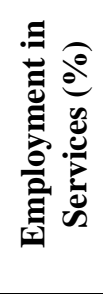 & 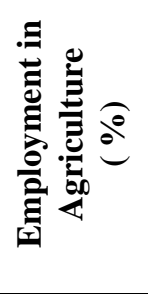 & 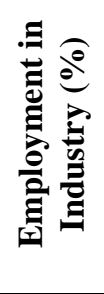 & 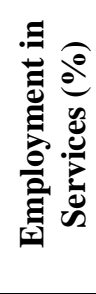 \\
\hline 2001 & 163.15 & 14.14 & 22.7 & 131.12 & 22.77 & 46.12 & 164.17 & 4.86 & 30.97 \\
\hline 2002 & 156.69 & 11.98 & 31.32 & 120.67 & 26.6 & 52.73 & 163.13 & 5.04 & 31.83 \\
\hline 2003 & 155.32 & 11.95 & 32.8 & 108.38 & 30.57 & 61.04 & 161.96 & 5.06 & 32.98 \\
\hline 2004 & 151.17 & 13.73 & 35.1 & 110.04 & 28.88 & 61.08 & 154.65 & 7 & 38.34 \\
\hline 2005 & 151.63 & 13.3 & 35.07 & 110.2 & 27.62 & 62.18 & 143.09 & 9.21 & 47.7 \\
\hline 2006 & 149.45 & 13.53 & 37.02 & 110.14 & 27.63 & 62.23 & 127.94 & 14.61 & 57.45 \\
\hline 2007 & 146.85 & 14.42 & 38.72 & 110.49 & 28.28 & 61.22 & 137.19 & 12.32 & 50.49 \\
\hline 2008 & 142.62 & 14.37 & 43 & 109.83 & 29.3 & 60.87 & 136.83 & 12.77 & 50.4 \\
\hline 2009 & 143.54 & 11.73 & 44.72 & 108.58 & 30.76 & 60.65 & 132.56 & 13.74 & 53.7 \\
\hline 2010 & 138.45 & 11.73 & 49.82 & 106.46 & 32.28 & 61.26 & 120.92 & 13.29 & 65.79 \\
\hline 2011 & 134.62 & 12.41 & 52.96 & 106.57 & 33.79 & 59.64 & 122.69 & 18.24 & 59.06 \\
\hline 2012 & 132.69 & 11.96 & 55.35 & 102.4 & 37.44 & 60.16 & 127.26 & 16.98 & 55.76 \\
\hline 2013 & 132.26 & 11.96 & 55.79 & 95.48 & 43.48 & 61.03 & 115.99 & 21.69 & 62.32 \\
\hline 2014 & 131.41 & 12.16 & 55.58 & 98.34 & 39.74 & 61.91 & 117.05 & 20.75 & 62.2 \\
\hline 2015 & 131.67 & 12.58 & 56 & 98.15 & 38.1 & 63.74 & 118.9 & 19.18 & 61.92 \\
\hline 2016 & 131.74 & 12.53 & 55.72 & 95.04 & 38.87 & 66.08 & 116.51 & 18.96 & 64.51 \\
\hline 2017 & 133.62 & 12.45 & 53.93 & 91.07 & 39.29 & 69.64 & 116.46 & 19.33 & 64.21 \\
\hline
\end{tabular}

Contd...

\begin{tabular}{|c|c|c|c|c|c|c|c|c|c|}
\hline \multirow[b]{2}{*}{ Year } & \multicolumn{3}{|c|}{ Cambodia } & \multicolumn{3}{|c|}{ Laos } & \multicolumn{3}{|c|}{ Myanmar } \\
\hline & 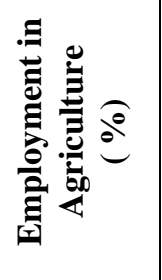 & 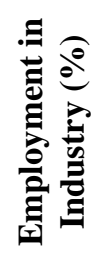 & 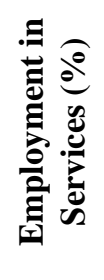 & 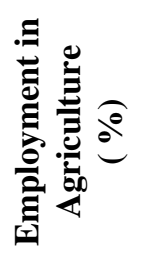 & 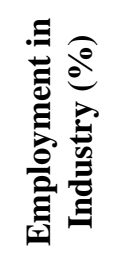 & 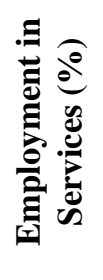 & 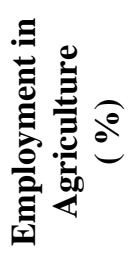 & 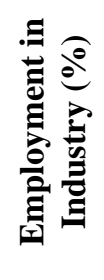 & 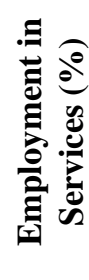 \\
\hline 2001 & 140.48 & 20.89 & 38.62 & 164.53 & 7.18 & 28.28 & 150.25 & 20.25 & 29.5 \\
\hline 2002 & 141.08 & 20.78 & 38.13 & 162.75 & 8.24 & 29 & 148.05 & 21.26 & 30.69 \\
\hline 2003 & 141.8 & 20.97 & 37.22 & 161.32 & 8.78 & 29.89 & 145.22 & 21.66 & 33.11 \\
\hline 2004 & 140.83 & 20.62 & 38.54 & 159.46 & 9.53 & 31.01 & 142.01 & 22.63 & 35.35 \\
\hline 2005 & 141.57 & 19.56 & 38.86 & 156.99 & 10.62 & 32.38 & 138.95 & 23.29 & 37.76 \\
\hline 2006 & 141.14 & 20.04 & 38.82 & 155.6 & 11.06 & 33.33 & 135.43 & 23.93 & 40.64 \\
\hline 2007 & 141.76 & 19.18 & 39.06 & 153.49 & 12.64 & 33.87 & 132.63 & 24.7 & 42.66 \\
\hline 2008 & 144.46 & 17.15 & 38.39 & 150.72 & 13.85 & 35.42 & 128.35 & 26.69 & 44.95 \\
\hline 2009 & 126.19 & 24.94 & 48.94 & 147.39 & 14.93 & 37.68 & 124.54 & 27.97 & 47.49 \\
\hline 2010 & 108.33 & 32.51 & 59.16 & 142.91 & 16.64 & 40.45 & 120.88 & 29.64 & 49.47 \\
\hline 2011 & 87.71 & 40.54 & 71.75 & 141.04 & 17.03 & 41.92 & 117.75 & 30.52 & 51.73 \\
\hline
\end{tabular}


Does The Recent Global Business Growth Exhibit An Inclusive Growth? A Research on Socio - Economic Status of Least Developed Nations in Asia

\begin{tabular}{|l|r|c|c|c|c|c|c|c|c|}
2012 & 66.5 & 50.48 & 83.02 & 134.21 & 18.85 & 46.93 & 114.31 & 31.05 & 54.63 \\
\hline 2013 & 64.28 & 51.08 & 84.64 & 130.96 & 18.69 & 50.34 & 111.18 & 31.04 & 57.78 \\
\hline 2014 & 60.95 & 52.12 & 86.93 & 128.53 & 18.84 & 52.62 & 107.72 & 31.6 & 60.67 \\
\hline 2015 & 57.6 & 53.66 & 88.74 & 126.24 & 18.96 & 54.79 & 103.03 & 32.87 & 64.09 \\
\hline 2016 & 54.87 & 54.1 & 91.03 & 124 & 19.09 & 56.92 & 102.12 & 31.87 & 65.99 \\
\hline 2017 & 53.41 & 54.03 & 92.56 & 122.69 & 19.3 & 58.01 & 99.34 & 32.38 & 68.28 \\
\hline
\end{tabular}

Contd...

\begin{tabular}{|c|c|c|c|c|c|c|c|c|c|}
\hline \multicolumn{10}{|l|}{ 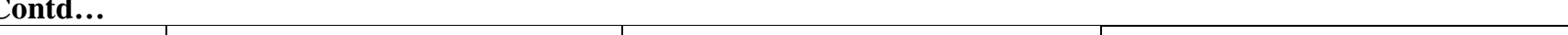 } \\
\hline & \multicolumn{3}{|c|}{ Nepal } & \multicolumn{3}{|c|}{ Timor } & \multicolumn{3}{|c|}{ Yemen } \\
\hline Year & 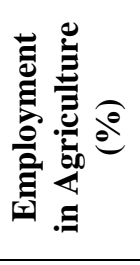 & 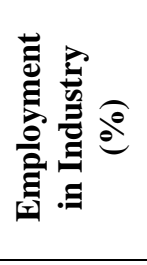 & 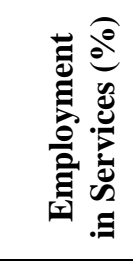 & 离总 & 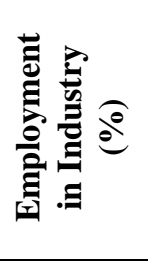 & 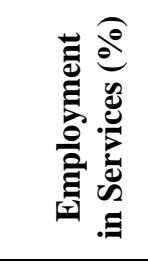 & 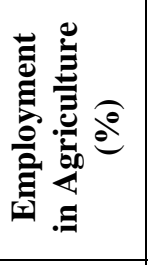 & 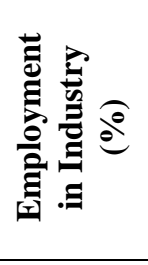 & 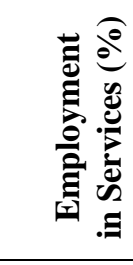 \\
\hline 2001 & 132.02 & 26.79 & 41.18 & 99.76 & 16.16 & 84.08 & 110.09 & 20.29 & 69.61 \\
\hline 2002 & 147.82 & 11.42 & 40.77 & 105.2 & 15.71 & 79.09 & 98.43 & 22.27 & 79.29 \\
\hline 2003 & 15012 & 9.69 & 40.18 & 112.28 & 15.81 & 71.91 & 85.66 & 24.66 & 89.68 \\
\hline 2004 & 151.59 & 9.47 & 39.15 & 121.85 & 15.3 & 62.86 & 70.53 & 27.09 & 102.39 \\
\hline 2005 & 152.36 & 10.3 & 38.17 & 120.47 & 15.62 & 63.9 & 68.17 & 25.71 & 106.11 \\
\hline 2006 & 152.03 & 11.88 & 37.66 & 124.44 & 15.13 & 60.42 & 64.52 & 27.51 & 107.97 \\
\hline 2007 & 151.3 & 15.33 & 36.82 & 120.28 & 15.34 & 64.38 & 61.37 & 29.03 & 109.61 \\
\hline 2008 & 148.25 & 14.77 & 36.44 & 114.99 & 16.56 & 68.44 & 59.36 & 30.31 & 110.32 \\
\hline 2009 & 148.84 & 14.98 & 36.39 & 106.22 & 17.81 & 75.44 & 56.62 & 32.83 & 110.55 \\
\hline 2010 & 149.42 & 14.9 & 35.6 & 101.29 & 17.54 & 81.16 & 51.84 & 33.91 & 114.25 \\
\hline 2011 & 149.84 & 15.01 & 35.26 & 92.14 & 20.59 & 87.27 & 62.21 & 30.73 & 107.06 \\
\hline 2012 & 147.98 & 15.49 & 37 & 98.84 & 21.57 & 88.59 & 66.16 & 30 & 103.82 \\
\hline 2013 & 146.49 & 15.94 & 38.01 & 85.69 & 22.79 & 91.52 & 71.9 & 28.77 & 99.83 \\
\hline 2014 & 144.73 & 15.92 & 39.32 & 82.96 & 23.74 & 93.31 & 79.01 & 27.37 & 93.62 \\
\hline 2015 & 143.77 & 15.71 & 40.3 & 81.22 & 22.99 & 95.78 & 89.7 & 28.98 & 81.32 \\
\hline 2016 & 143.58 & 15.8 & 40.71 & 51.31 & 23.85 & 125.04 & 91.63 & 30.18 & 78.19 \\
\hline 2017 & 142.55 & 16.36 & 41.09 & 51.71 & 25.53 & 122.75 & 108.6 & 25.59 & 65.81 \\
\hline
\end{tabular}

coefficient of predicts and constant value are arrived as a1

The above table shows the sector-wise employment in the least developed countries of Asia. In Afghanistan, the percentage of employment in agriculture and Industrial sector has declined whereas in service sector the percentage of employment has increased during same study period. Bangladesh, Bhutan, Cambodia, Laos, Myanmar, Timor showed more percentage of employment in the industrial and service sector during this study period. This is a good sign for the development of these countries. Whereas in Nepal the percentage of employment in the agriculture sector has slowly increased during this period and declined in the Industrial sector and services sector. It is not a good sign for the development of the country's economy. Yemen had shown a very small percentage of employment growth in the industrial sector and a slight decline in Agricultural and service sector.

\section{SUMMARY AND CONCLUSION}

The results of table 1 to 3 explain the regression analysis for gross national income. The independent variables considered for the test are 'Total Population, GNI per capita growth (annual \%), and Poverty headcount ratio at national poverty lines (\% of the population). By running regression test the
$=0.00001043, \alpha 1=975.485, \alpha 2=0.00002755$ and $\varepsilon 1=$ 0.823.Here $\mathrm{P}$ value is much less than 0.05 (i.e.0.000) we reject the null hypothesis.

The results of Tables 4 to 6 reflected the results of the regression analysis for foreign direct investment -inflow. The Significance (P Value) of the model is 0.00 , which is less than the stipulated P-Value of 0.05 . So this test is statistically significant.

Tables 7 to 9 show that the results of regression analysis for literacy rate (adult). The independent variables considered for the test are 'Population (total)', 'Literacy rate- adult female (\% of female of age 15 and above)' and 'Literacy rate - adult male (\% of male of age 15 and above)'. By running that regression test the coefficient of predicts and constant value are arrived as a3 $=0.662, \alpha 7=0.495, \alpha 8=0.492, \alpha 9=1.286$ and $\varepsilon 3=$ 0.999 .

Table 10, 11 and 12 show that the Model Summary - Life expectancy at birth (total), Regression, Error values and Coefficients of dependent variables. The Significance ( $P$ Value) of the model is 0.00 , which is less than the stipulated P-Value of 0.05 . 
So this test is statistically significant. The result of regression test revealed that the coefficient of predicts and constant value are $\mathrm{a} 4=0.016, \alpha 10=0.526, \alpha 11=0.472, \alpha 12=-0.072, \alpha 13=$ -0.082 and $\varepsilon 3=0.998$. Hence from the above results, we can conclude that there is a significant relationship between the variables in the linear regression model.

Table No 13 shows that the growth rate of GDP per capita (annual \%) is based on the constant local currency of a country. Out of these nine LDC's Afghanistan, Cambodia, Nepal, Timor -Leste and Yemen showed negative growth of GDP per capita growth (annual \%) for some years. An economy with negative growth rates has declining wage growth and an overall reduction of the money supply. Whereas Bangladesh, Bhutan, Laos, and Myanmar had positive per capita growth (annual \%) in this study period. It indicates the growth of the economy and tends to reflect an increase in productivity.

Table 15 shows the Sector wise percentage of employment in the least developed countries from 2001-2017 in Asia. Except for Nepal and Yemen all other least developed countries showed improvement in the percentage of employment in the Industrial sector and service sector. As per the statistical report in the year 2017, the percentage of employment in all the sectors had slightly decreased in Yemen. Definitely, it will affect the economy.

It is concluded from the various analyses that, all the least developed countries should concentrate to create employment opportunities in various fields. This would improve the standard of living of the people. These countries should put forth efforts to reduce the import of goods and services and increase the exports of goods and services. The government should provide proper education to the children. Improve literacy rate, accept foreign direct investment inflow. The governments of these nations should also initiate measures to control the population, reduce the poverty situation, to reduce HIV/Aids diseases. Government should also conduct awareness programmes, Campaign to the public. If the countries concentrate on all the above they will move to the list of developing and thereafter developed countries in the future.

\section{REFERENCES}

1. Final Act and Report of the United Nations Conference on Trade and Development, Annex A.I.1, United Nations publication, Sales No. 64.II.B.11, p. 11.

2. United nations conference on trade and development. http://unctad.org/en/Pages/ALDC/Least\%20Developed\%20Countries/ LDCs.aspx.

3. Report of the Committee for Development Planning on the seventh session (22 March-1 April 1971), Official Records of the Economic and Social Council, Fifty-first session, 1971, Supplement No. 7.

4. Dutton, D.B., and Levis, S. (1989), Overview, Methodological Critique, and Reformulation, in J.P. Bunker, D.S. Gomby, and B.H. Kehrer (Eds.), Pathways to Health. Melno Park, CA: The Henry J. Kaiser Family Foundation, pp. 29-69.

5. Grimmett, P. (1995), Crafting the Curriculum of Teacher Education" In Re-forming Teacher Education: Problems and Prospects, edited by Suzanne Majhanovich, 55-76. London, Ontario:TheAlthouse Press.

6. AKM AbdusSabur (1999), "Bangladesh Foreign Policy in the PostCold War Era : Challenges and Options", in, Mukesh Kumar Kayathwal (ed.), Security and Foreign Policy in South Asia, Jaiput: Poineer Publishers, 1999.

7. Dhungel, K.R.( 2003), "Income and Price Elasticity of the Demand for Energy: A Macro-level Empirical Analysis”, Pacific and Asian Journal of Energy, Vol. 13, No. 2, pp 73-84.
8. Weggel, Oskar (January 2006). "Cambodia in 2005: Year of Reassurance". AsianSurvey 46 (1):151-161. Doi:10.1525/as.2006.46. 1.155. JSTOR 10.1525/as 2006.46.1.155.

9. Lee, Joosung J (May-June 2011) "An Outlook for Cambodia's Garment Industry in the Post-Safeguard Policy Era" Asian Survey 51 (3):570.

10. Bangladesh Continues to Reduce Poverty But at Slower Pace October 24, 2017 the world Bank October 3, 2016.

11. Misha, Farzana; Sulaiman, Munshi. "Bangladesh Priorities: Poverty, Sulaiman and Misha /Copenhagen Consensus. Copenhagen Consensus Retrieved 7 April 2016.

12. Bangladesh Can Overcome Extreme Poverty through More Inclusive Growth -the world Bank October 3, 2016.

13. Cecilia Tortajada (2016) Bhutan and Nepal: two 'least developed countries' that could change the face of Asia - December 2016. 